\title{
PLURALISME SEBAGAI BENTUK PERLAWANAN \\ TERHADAP RADIKALISME AGAMA
}

Oleh: Theodorus Uheng Koban Uer

\begin{abstract}
Abstrak:
Masalah yang dikemukakan dalam penulisan artikel ini adalah apakah dengan kehadiran pluralisme dalam berbagai bidang kehidupan sosial budaya khususnya bidang kehidupan agama sungguh menjadi bentuk perlawanan terhadap radikalisme agama. Dan, upaya apakah yang perlu dilakukan agar pluralisme semakin efektif menjadi bentuk perlawanan terhadap radikalisme agama. Tujuan penulisan ini untuk menunjukkan bahwa radikalisme agama telah ada di Indonesia dan telah banyak korban berjatuhan sehingga perlu dilakukan upaya-upaya yang lebih efektif oleh organisasi atau lembaga-lembaga jemaat yang pluralistik bersama pemerintah dan badan keamanan untuk menghadapi kekejaman dan kebrutalan kaum radikalisme agama atau teroris. Metode yang dipakai adalah membaca berbagai kepustakaan dan mendeskripsikan berbagai informasi dari majalah dan surat kabar dan mengolah informasi menjadi data untuk disajikan dalam tulisan tersebut.

Hasilnya menunjukkan berbagai fakta bahwa beberapa organisasi keagamaan terus memantau dan bekerjasama dengan pihak keamanan yang bekerja dan bertindak optimal namun perlu ditingkatkan melalui kerjasama antarkelompok pluralis untuk terus waspada dan meningkatkan kerjasama antar berbagai komunitas keagamaan untuk mengurangi kekejamanan dan kebrutalan yang dilakukan oleh kelompok teroris khususnya ISIS ( Islamic State of Irak and Syria).
\end{abstract}

Kata-kata kunci: pluralisme, radikalisme agama.

\section{PENDAHULUAN}

\subsection{Konteks Penelitian}

$\mathrm{U}$

mat Kristiani khususnya yang mendiami wilayah Nusantara baru saja merayakan dua hajatan besar. Pertama, perayaan Paskah yang dirangkai dalam Trihari Suci : Kamis Perjamuan Ekaristi Agung yaitu peringatan Kristus mengadakan Ekaristi pada Perjamuan Malam Terakhir bersama murid-murid-Nya; Jumat Agung yakni peringatan Kristus menderita, sengsara, wafat disalibkan untuk membebaskan umat manusia dari dosa dan maut; perayaan Malam Paskah dan Paskah Kebangkitan Tuhan yang menjadi puncak dari semua perayaan tersebut. Dengan cinta-Nya yang agung dan mulia Kristus membebaskan umat manusia baik yang hidup dan yang mati dari dosa melalui satu tindakan penyelamatan oleh Yesus Kristus Tuhan dan Allah kita.

Kedua, warga negara Indonesia merayakan pesta demokrasi dalam Pemilihan Umum (Pemilu) pemilihan Presiden dan Wakil Presiden serta Pemilihan anggota Legislatif (DPR Pusat dan Daerah serta DPD (Dewan Perwakilan Daerah) yang dilakukan serentak di seluruh Nusantara. Suatu kegiatan yang melelahkan para penyelenggara (KPU) dan segenap jajarannya mulai dari Pusat sampai ke Daerah dan pelosok-pelosok wilayah Indonesia. Suatu kegiatan yang 
sungguh berat dan menuntut banyak korban. Banyak anggota KPPS yang meninggal dan anggota keamanan serta hampir lima ratusan yang sakit dan dirawat di Rumah Sakit setempat.

Ketika perayaan Paskah berlangsung di mana-mana kaum radikal atau teroris berupaya mengacaukan situasi perayaan tersebut. Dan yang paling dahsyat ialah tiga buah gereja dan hotel di Srilangka-Ceylon dibakar oleh kaum radikal. Dan di Indonesia mereka mengancam namun sempat dicegah. Gerakan radikalisme sudah menyebar di mana-mana dan sedang serta sudah dan terus berusaha menghancurkan kesatuan dan persatuan bangsa. Dasar negara Pancasila digerogoti oleh Islam radikal yang ingin mendirikan negara Islam (khilafah) yaitu pembentukan negara di mana warga negara melaksanakan syariat Islam dalam kehidupan bernegara.

Fakta menunjukkan sikap toleransi dan rasa solidaritas antara kelompok yang berbedabeda budaya agama, dan sebagainya tidak cukup menjamin untuk meredam radikalisme. Oleh sebab itu diharapkan dengan adanya pluralisme yakni keadaan masyarakat yang majemuk di berbagai bidang kehidupan dapat menjadi bentuk perlawanan terhadap kaum radikal agama. Atau sekurang-kurangnya membentuk kerja sama antarorganisasi keagamaan untuk memantau gerakan-gerakan radikalisme. Karena gerakan radikalisme terus-menerus mengubah pola kerjanya. Mereka menggunakan keluarga untuk mencapai tujuannya bahkan perempuan dan anak-anak diperalat untuk melakukan bom bunuh diri seperti yang terjadi di Sibolga pada 13 Maret 2019 yang lalu.

\subsection{Fokus Penelitian}

Bertumpu pada sekilas latar belakang atau konteks penelitian di atas maka penulis memfokuskan tulisan ini pada dua masalah berikut.

(1) Apakah hadirnya pluralisme dalam masyarakat dapat menjadi bentuk perlawanan terhadap radikalisme agama.

(2) Manakah cara yang efektif yang dapat dilakukan oleh kelompok pluralis dalam masyarakat untuk menjadi bentuk perlawanan terhadap radikalisme agama.

\subsection{Tujuan Penelitian}

(1) Untuk menunjukkan data dan menginformasikan bahwa kelompok teroris atau radikalis sudah ada dan beraksi di Nusantara dan kelompok pluralisme agama perlu menjadi bentuk perlawanan lebih efektif.

(2) Untuk meningkatkan kerja sama antar kelompok pluralisme bersama pemerintah dan keamanan agar terus memantau gerak kaum teroris karena kelompok teroris terusmenerus mengubah pola dan cara kerjanya.

\section{PLURALISME VERSUS RADIKALISME}

\subsection{Beberapa Aspek Pluralisme dalam Masyarakat Demokrasi}

Menurut Otto Gusti Madung dalam bukunya berpendapat bahwa demokrasi modern berpijak pada sebuah postulat normatif tentang kebebasan individual yang setara bagi setiap manusia. Substansi afirmatif ini tidak saja menjadi jaminan bagi syarat-syarat kebebasan dan perwujudan diri individual seperti tampak dalam bahasa hukum atau bahasa hak-hak individual. Lebih dari itu, ia juga memberi jaminan kepastian atas koeksistensi damai, relasi yang kooperatif dan solider antarmanusia sebagai sebuah komunitas sosial dan politik. Dengan demikian bagi 
formasi identitas individu dan kolektif berlaku bahwa norma-norma umum memainkan peran konstitutif'. ${ }^{1}$

Bertumpu pada gagasan tersebut dapat dikatakan bahwa perwujudan demokrasi tampak dalam pluralisme. Pluralisme berarti banyak dan bermacam-macam. Ada tiga aspek atau ciri yang merujuk pada pengertian pluralisme. Pertama, pluralisme dianggap sebagai deskripsi keberagaman sosial yang merupakan esensi sebuah masyarakat demokratis. Artinya setiap warga memiliki kebebasan berpikir dan berpendapat sehingga setiap warga bebas memilih dan menentukan pandangan hidup serta pandangan politiknya sendiri. Dan apabila dua pilihan saja akan lebih mudah dia memilih $\mathrm{X}$ atau Y. Namun jika muncul banyak pilihan maka akan muncul konflik batin yang bersifat intern dan ekstern. Coba kita simak pelaksanaan Pemilu di Indonesia pada 17 April 2019 yang baru lalu. Pada waktu memilih presiden dan wakil presiden, karena hanya dua pasang maka akan lebih mudah. Namun ketika memilih calon anggota legislatif para konstituen bingung lalu mencoblos pada tempat yang salah atau membiarkan kosong sebab tak ada gambar atau foto dan hanya nama calon yang dicantumkan. Akibat yang lebih lanjut ialah ketika mulai perhitungan suara dilaksanakan para petugas di TPS dan anggota KPPS serta saksi menjadi bingung gerah dan stress. Para petugas banyak yang sakit bahkan meninggal mungkin karena takut dianggap memanipulasi suara; apalagi mereka bekerja lebih dari 24 jam tanpa istirahat. Memang kenyataan menunjukkan bahwa partisipasi para kontestan dalam pemilu ini lebih dari $80 \%$ akan tetapi yang menjadi pertanyaan adalah apakah mereka sudah tepat memilih sesuai hati nuraninya. Akhirnya terjadi di mana-mana Pemilu susulan, Pemilu ulang, dan sebagainya di banyak TPS di seluruh Nusantara.

Kedua, pluralisme dipandang dari sudut pandang normatif diinterpretasi sebagai basis nilai sebuah kehidupan bersama. Para founding fathers pendiri NKRI menetapkan Pancasila sebagai basis nilai sebuah kehidupan bersama dalam negara Indonesia yang baru saja terlepas dari penjajahan Belanda selama bertahun-tahun. Sebagai basis nilai-nilai kehidupan bersama Pancasila memuat pluralisme secara utuh sehingga harus terus menerus diperjuangkan untuk dilestarikan. Ketuhanan Yang maha Esa menunjukkan bahwa semua agama yang ada di Indonesia harus hidup berdampingan, saling menghargai dan menghormati. Tidak ada kelompok agama yang memandang kelompok lain sebagai ancaman sehingga mau memisahkan diri. Hal ini bertentangan dengan Kemanusiaan Yang Beradab yang sudah tertanam dalam pada setiap budaya asli Indonesia dan seterusnya akan menghancurkan persatuan Indonesia karena NKRI adalah harga mati yang 'disumpahkan' dalam Sumpah Pemuda pada Oktober 1928. Oleh sebab banyak orang terperangah dan terkesima ketika menyaksikan dua unjuk rasa raksasa yang terjadi pada tanggal 04 bulan November yang popular disebut unjuk rasa 411 dan 2 Desember 2016. Aksi ini mau memerotes omongan Gubernur DKI (Ahok) dengan slogan yang terkenal "kami ini Muslim dan kami akan membela Islam". Sebagian besar masyarakat Islam mulai bertanya-tanya tentang isi pernyataan ini. Setelah ditelaah maka muncul reaksi balik dari sebagian besar warga negara Indonesia yang menyatakan "Pancasila, NKRI, Bhineka Tunggal Ika, UUD 1945 adalah harga mati sebagai nilai dasar bagi bangsa Indonesia."

Konsensus kesediaan untuk saling menerima dalam identitas masing-masing seperti yang dinyatakan dalam Sumpah Pemuda karena menjadi orang Indonesia bukan orang Jawa yang ada di Indonesia, bukan Sulawesi atau orang Irian yang ada di Indonesia, atau bukan Sumatra yang Islam yang ada di Indonesia dan bukan orang Flores dan NTT yang beragama Kristen yang ada

${ }^{1}$ Otto Gusti Madung, Post-Sekularisme, Toleransi dan Demokrasi (Maumere: Ledalero, 2017), hlm. 117. 
di Indonesia melainkan kita adalah Orang Indonesia dan ini Rumah kita Indonesia. Agar tidak terulang lagi unjuk rasa seperti ini maka keberagaman yang tampak dalam Bhineka Tunggal Ika perlu dikelola dalam wacana dialog antara kelompok pluralisme sedemikian untuk mengurangi konflik berdarah yang sering terjadi di berbagai wilayah Nusantara.

Ciri ketiga yang berkaitan erat dengan ciri kedua adalah bahwa pluralisme dianggap mengganggu kesatuan sosial. Karena adanya keanekaragaman di berbagai bidang seperti ideologi, politik, budaya, agama, dan lain-lainnya dapat menghancurkan kohesi sosial. Pluralisme di berbagai bidang tersebut berpeluang menghancurkan kolektevisme.

Bidang politik misalnya, munculnya politik identitas. Pada masa perjuangan kemerdekaan Republik Indonesia, setiap warga memiliki konsensus untuk saling menerima dalam identitas masing-masing. Setiap warga negara Indonesia menghargai dan merasa memiliki (sense of belonging) Pancasila sebagai milik bersama dan milik setiap warga. Akan tetapi ketika politik identitas mengglobal, terutama ketika konsep-konsep Donald Trump Presiden USA dari partai Republik menjadi perhatian banyak orang, muncullah politik yang lebih mengutamakan emosi dan bukan fakta. Fakta yang kredibel dimanipulasi sedemikian melalui media sosial. Orang menolak sumber-sumber informasi yang kredibel dan lebih mudah percaya pada media massa yang menyelaraskan berita bohong untuk mendiskreditkan orang yang memiliki informasi yang benar. Dengan demikian hancurlah kebersamaan untuk hidup berdampingan. Atau hancurlah "live with others and live together". Sampai-sampai kehidupan keluarga atau kesuami-istrian pun menjadi berantakan. Misalnya, seperti yang terdengar dalam unjuk rasa 411 atau 212: "kami yang mayoritas harus dihargai dan dihormati dan diakui serta tidak boleh dikuasai oleh kamu yang minoritas". Contoh yang paling jelas terjadi di kabupaten Bantul-Yogyakarta. Seorang camat Katolik diangkat oleh Bupati ditolak sebagian besar rakyat yang beragama Islam. Akan tetapi setelah dilakukan survei dan Bupati mengumpulkan tokoh-tokoh masyarakat untuk memusyawarahkan hasil survei tersebut maka Camat tersebut diangkat kembali. Para tokoh masyarakat Bantul menyatakan "Pancasila, UUD 1945, NKRI, dan Bhineka Tunggal Ika adalah harga mati bagi bangsa ini."

\subsection{Radikalisme Agama}

Menurut arti kanonik, radikalisme adalah aliran atau paham yang menginginkan pembaharuan atau perubahan sosial, politik, religius, dan sebagainya dengan cara kekerasan dan drastis. Banyak agama di dunia mempunyai doktrin yang bersifat radikal. Yesus Kristus mengajarkan hukum cinta kasih secara radikal. "Inilah perintah-Ku bagimu, supaya kamu saling mengasihi, seperti Aku telah mengasihi kamu. Tidak ada kasih yang lebih besar daripada kasih seorang yang memberikan nyawanya bagi sahabat-sahabatnya. Kamu adalah sahabat-sahabat$\mathrm{Ku}$, jkalau kamu berbuat apa yang Kuperintahkan kepadamu.'(Yoh 15: 12 - 14). Hal ini berbeda dengan hukum atau perintah Musa dalam Taurat. "Rabi, perempuan ini tertangkap basah ketika ia sedang berbuat zinah. Musa dalam hukum Taurat memerintahkan kita untuk melempari perempuan-perempuan yang demikian. Apakah pendapat-Mu tentang hal itu. Dan ketika mereka terus-menerus bertanya kepada-Nya, Ia bangkit berdiri lalu berkata kepada mereka, "Barang siapa di antara kamu tidak berdosa, hendaklah ia yang pertama melemparkan batu kepada perempuan itu." Tetapi setelah mereka mendengar perkataan itu, pergilah mereka seorang demi seorang, mulai dari yang tertua. Akhirnya tinggallah Yesus seorang diri dengan perempuan itu yang tetap di tempatnya. Lalu Yesus bangkit berdiri dan berkata kepadanya, "Hai perempuan di 
manakah mereka. Tidak adakah seorang yang menghukum engkau?" Jawabnya, "tidak ada Tuhan." Lalu Yesus berkata, "Akupun tidak menghukum engkau. Pergilah dan jangan berbuat dosa lagi mulai dari sekarang." (Yoh 8: 4-5, 7,9-11).

Demikian pula pada hukum Islam yang mengajarkan damai, solidaritas dan toleransi seperti yang terdapat dalam ayat-ayat Al Qur'an. Berbeda dengan ajaran Islam radikal (ISIS). Seorang warga yang diketahui tidak memahami dasar-dasar Islam, ditangkap dan dimasukkan dalam penjara dan dipaksa membaca Al Quran. Ada orang yang lain yang kedapatan merokok pada bulan Ramadan ditangkap dan dicambuki di jalan di bawah terik matahari. Demikianlah kekejaman dan kebrutalan yang dilakukan oleh kelompok ISIS terhadap sesamanya. Sedangkan mereka yang bukan penganut Muslim seperti Kristen, Katolik atau Hindu dibunuh, tempat ibadahnya dibakar dengan cara melakukan bom bunuh diri atau penganiayaan, pembunuhan dan kebrutalan serta kekejaman lainnya.

Kejadian-kejadian seperti ini telah berlangsung dalam negara Indonesia yang tercinta. Fakta atau kenyataan ini menunjukkan bahwa diperlukan pluralisme keagamaan yang selalu waspada dan bekerja sama dengan pemerintah dan keamanan negara. Organisasi yang sudah dibentuk oleh Nahdatul Ulama seperti GP Ansor dan Banser sudah melakukan tugas monitoringnya namun harus lebih diefektifkan lagi sebab kaum radikal atau ISIS bekerja secara sporadis di seluruh wilayah Nusantara dan menggunakan segala macam cara yang berbentuk kekejaman dan kebrutalan untuk mencapai maksaudnya.

\section{PLURALISME SEBAGAI BENTUK PERLAWANAN TERHADAP RADIKALISME AGAMA}

Bangsa Indonesia memiliki beragam-ragam suku, agama, budaya, etnis, dan bahasa. Keberagam ini perlu dikelola dalam bentuk dialog secara baik dan benar. Nilai-nilai Pancasila harus dihayati dan juga dikelola secara utuh dan benar. Mulai dari Ketuhanan Yang Maha Esa. Kemanusiaan Yang Adil dan Beradab, Persatuan Indonesia, Kerakyatan Yang Dipimpin oleh Hikmah Kebijaksanaan dalam Permusyawaratan Perwakilan, dan Keadilan Sosial bagi Seluruh Rakyat Indonesia. Konsensus untuk saling menerima dalam identitas masing-masing perlu terusmenerus ditumbuhkembangkan dan dikelola sedemikian rupa agar Pancasila sungguh-sungguh menjadi milik warga dan bangsa ini baik secara kolektif maupun secara individu. Dengan demikian pluralisme dalam sistem demokrasi akan sungguh-sungguh menjadi jaminan dalam menangkal berbagai gejolak yang muncul seperti yang dilakukan oleh kaum radikalisme agama dalam berbagai bentuk organisasi bentuk-bentuk teroris yang bernaung di bawah ISIS.

ISIS adalah singkatan dari Islamic State of Irak and Syriah: suatu radikalisme Islam yang bertujuan memurnikan ajaran-ajaran Islam dengan cara kekerasan dan kekejaman baik terhadap penganut agama Muslim sendiri maupun terhadap agama-agama lain yang dianggap menyelewengkan ajaran-ajaran agama Islam. Karena Islam adalah agama yang paling benar dan murni. Ajaran radikalisme agama ini sudah mendunia. Kekejaman, kebrutalan, dan pembunuhan telah menjalar ke seluruh dunia yang dilakukan dalam bentuk perang dan terorisme.

Kelompok teroris ini sudah diusir dimana-mana namun gerakan terus menjalar ke manamana ke seluruh dunia sehingga gerakan tersebut menimbulkan banyak kegelisahan dan ketakutan bagi bangsa-bangsa terutama kelompok agama. Para pemimpin Islam di seluruh dunia pernah mengutuk keras ideologi yang dianut dan diperjuangkan ISIS. Mereka menuduh militant 
ISIS telah memanipulasi ajaran Islam yang sesungguhnya. Pada tahun 2014 lebih dari seratus orang cendekiawan Muslim menulis surat terbuka kepada pemimpin ISIS Abu Bakr al- Baghdadi menyatakan dengan tegas bahwa kelompok itu telah menafsirkan salah ajaran Islam menjadi sebuah agama yang penuh kekejaman, kebrutalan, penganiayaan dan pembunuhan.

Meskipun perlawanan terhadap kelompok ini terjadi di mana-mana baik dalam peperangan seperti terjadi di Nigeria, atau pengusiran seperti terjadi di Korbani sebuah kota yang sangat strategis di perbatasan antara Suriah dan Turki, juga dengan pelarangan seperti yang dilakukan di Indonesia dengan pelarangan gerakan HTI namun gerakan ini telah bergerak terus dengan nama lain yakni Komunitas Royatul Islam (KARIM) yang menampilkan simbol-simbol HTI berupa bendera dan topi tauhid dan dakwah. Selain KARIM yang terus bergerak di kalangan anak muda bangsa ini, juga ada gerakan Jemaah (JAD) yang tersebar di Sibolga dan pelaku bom diri seorang istri teroris, sesungguhnya telah beraksi di Surabaya beberapa waktu yang lalu dan dalam waktu yang singkat beraksi di Lampung. Para pengamat teroris menyatakan bahwa pola kelompok yang berafiliasi dengan ISIS telah mengubah pola gerakannya dari biasanya bergerak dalam bentuk kelompok, kini beradaptasi dalam unit yang lebih kecil setingkat keluarga. Ini adalah strategi untuk menghindari pelacakan dari aparat.

Dengan demikian aksi yang dilakukan keluarga atau pelaku tunggal akan terus menjadi bentuk aksi teror ke depan. Negara Indonesia yang terdiri atas banyak pulau dan kepulauan akan mudah dikuasai karena kegiatan teroris akan sulit dilacak apabila wilayah-wilayah terpencil tidak ditempatkan aparat keamanan yang siap siaga. Sebab ISIS juga tega melibatkan perempuan dan anak-anak untuk melakukan aksinya. ISIS memang menghalalkan segala cara untuk mencapai tujuannya. Wilayah atau kota yang selama ini dinyatakan aman harus terus dijaga. Kita semua, baik aparat keamanan, pemerintah mulai dari desa sampai ke kota, lembaga-lembaga keagamaan dan kemasyarakatan harus terus waspada menjaga anak-anak kita karena mereka mudah diperalat dan 'dicuci' otaknya. Kelompok teroris terus-menerus mengubah pola kerjanya baik melalui keluarga atau perorangan. Oleh sebab itu waspadalah dan berjaga-jagalah selalu.

\section{PENUTUP}

Bagaimana bentuk dan cara perlawanan terhadap radikalisme agama? Setiap agama memiliki bentuk dan cara perlawanan masing-masing terhadap radikalisme agama atau kaum teroris. Kita sudah membaca teguran berupa surat yang disampaikan oleh para pemimpin Islam di seluruh yang mengutuk keras ideologi yang diperjuangkan ISIS. Mereka menuduh militant ISIS telah membajak ajaran Islam yang sesungguhnya. Pada tahun 2014 lebih dari seratus orang cendekiawan menulis surat terbuka kepada pemimpin ISIS, Abu Bakr al-Baghdadi, menyatakan dengan tegas bahwa kelompok militan itu telah menafsirkan salah ajaran Islam menjadxi sebuah agama yang penuh kekejaman, kebrutalan, penganiayaan dan pembunuhan. Kenyataan menunjukkan bahwa tak ada perubahan perilaku ISIS. Bahkan mereka semakin brutal dan mengorbankan perempuan dan anak-anak dalam aksinya itu dan dalam bentuk terror tunggal yang gerakannya sulit terdeteksi. Oleh karena itu diharapkan para pemimpin agama mengajak kaum muda agar tetap waspada setiap gerak yang mencurigakan di berbagai tempat keramaian atau perilaku para pendatang baru di wilayah tertentu.

Kelompok Islam moderat di Indonesia menyatakan bahwa walaupun Hizbul Tahrir (HTI)

telah dibubarkan pemerintah namun semua warga harus tetap waspada karena ISIS telah 
membentuk gerakan baru seperti Komunitas Rakyat Muslim (KARIM) yang mengenakan simbol-simbol HTI seperti bendera dan topi tauhid serta dakwah.

Hal-hal tersebut dilakukan oleh kaum moderat Islam. Dan bagaimana kita yang beragama Kristen katolik serta agama-agama dan keyakinan lain. Masing-masing kita tentu memiliki cara sendiri-sendiri. Dan bagaimana kita sebagai orang Katolik? Kita baru saja merayakan Minggu Kerahiman Ilahi. Kita menolak semua bentuk kekerasan. Bahkan kita harus mengampuni orangorang yang menganiaya kita. Kita harus berdoa bagi mereka seperti Yesus berdoa bagi yang menyengsarakan dan menyalibkan Dia. Ketika Yesus sedang menderita di Salib Ia berdoa "Ya Bapa ampunilah mereka sebab mereka tidak tahu apa yang mereka perbuat." (Luk 23: 34). Sementara itu kita perlu meningkatkan kerja sama, toleransi yang lebih berkualitas dan rasa solider antar kita agar mampu menangkal ajaran-ajaran sesat atau kebohongan-kebohonga untuk menabur benih-benih kebencian dan fitnah di antara kita.

\section{Daftar Kepustakaan}

\section{$\underline{\text { Buku }}$}

Lembaga Alkitab Indonesia (LAI), Alkitab Deuterokanonika, diterbitkan dan dicetak oleh Lembaga Alkitab Indonesia, diterima dan diakui oleh Konferensi Wali Gereja Indonesia, dicetak 2013, Jakarta.

Madung, Otto Gusti, Post-Sekularisme, Toleransi dan Demokrasi, Maumere, Penerbit Ledalero, 2017.

Magnis-Suseno, Frans, Praktek Moral Dasar Kenegaraan Modern, Jakarta, Gramedia Pustaka Utama, 2016.

Walker, D.F, Konkordansi Alkitab, Penerbit Kanisius Yogyakarta dan BPK Gunung Mulia, Jakarta, 1994.

\section{$\underline{\text { Jurnal }}$}

Dhedhu, Frederikus, Politik dan Religiositas, Atma Reksa Jurnal Pastorald dan Kateketik, Vol III No 1 Edisi Januari- Juni 2018, halaman 21 - 27, Sekolah Tinggi Pastoral Atma Reksa, Ende.

Uer, Theodorus Uheng Koban, Konflik Sosial: Antara Kita, Kami, Kamu, dan Mereka, Jurnal Literasi No 3 Tahun III Desember 2018 halaman: 37-44, Program Studi Pendidikan Bahasa dan Sastra Indonesia, Universitas Flores Ende.

\section{Majalah}

Chatolic Life, Edisi April 2019, Penerbit Yayasan Pasindera Nusantara, Jakarta. 